\title{
Poem
}

\section{Memory for MMSE}

"Spell WORLD for me" I say.

"As in the world you live in."

You look me in the eyes,

Your face drawn and taught with anticipation.

You rub your forehead,

Slowly, thoughtfully,

The veins on your hand shining blue

Under the fluorescent lights of the tiny room.

I can visualize the letters forming in your mind

Each coming out like tiny droplets...

"W, O, R"..

You pause.

Your eyes meet mine

They speak volumes...

But I have to remain silent.

I give you an encouraging smile,

You shift in your chair and start over again.

"W, O, R...."

What do I know of the world you live in? You are afraid to go outside for fear of falling, But you still enjoy playing cards with friends Although they come by to see you less often.

You have not seen your son in years,

But you live for his Christmas cards.

You throw up your hands and finish the word, The last letters jumbled and almost incoherent.

You have a look in your eyes,

Of embarrassment, defeat, frustration.

But you manage to smile at me, as if to let me know It's not my fault.

"Good," I say...

Sounding a bit too enthusiastic...

"Now spell WORLD backwards."

As in, the world you have lived in, backwards?

Backwards through the years?

But what do I know of the world you have lived in?

Before we started this exercise,

You told me of your early years,

Growing up in northern Ontario.

How you met your wife over 50 years ago,

And how you worked,

Full days,

To make ends meet,

While you earned your college degree at night,

And became a school-teacher.
But these stories could not be scored.

I could not assign a number to your memories.

So I had to cut you short.

And now we sit here,

Each trying to keep up a show of optimism with one another...

As you struggle to spell a word

You taught to children years ago.

In geriatric assessment, I was often struck by the contradiction between conversation with these patients versus formal assessment with the Mini-Mental State Examination (MMSE). Many of the patients took pride in telling of their past accomplishments, sometimes in great detail. However, their memory could be deceiving, as completion of the Mini-Mental State Examination showed cognitive decline. I could see it, and so could they. It is difficult being witness to that moment of recognition.

\section{Pari Basharat BSc}

Medical student

London, Ont.

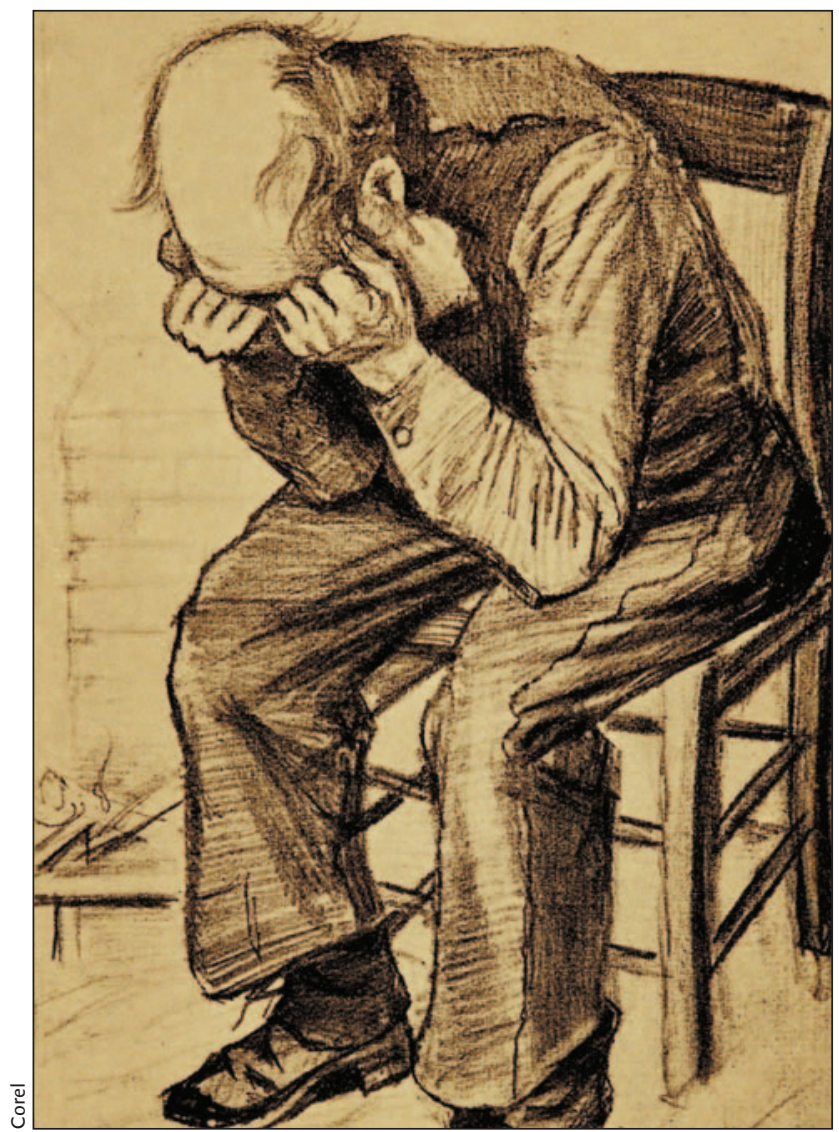

